\title{
Introduction of the Hungarian School Library System:
}

\section{Can Library Pedagogy Programs Save Us?}

\author{
Andrea Dömsödy
}

domsody.andrea@opkm.hu

National Pedagogical Library and Museum, Budapest, Hungary.

Eszterházy Károly University

\section{Marianna Edit Pataki}

patakima@gmail.com

Károlyi Mihály Hungarian and Spanish Bilingual High School, Budapest, Hungary.

Keywords: school libraries, school library association, library pedagogy program, Hungary

\section{Abstract}

The today's school libraries in Hungary trace back to the 18th century. After 1970 the school librarianship became an independent profession and library pedagogy was elaborated as well. Nowadays the Hungarian School Library Association provides the most support.

In spite of difficulties Hungarian school librarianship has much strength but needs to be improved in many fields yet. There are well operating libraries, committed teacher librarians and a good legislation. Library instruction is built into curriculum. In 2012 has changed the education policy, which also affected school libraries badly.

A way to save the profession is to elaborate the library pedagogy program and declare how libraries can support information literacy and independent learners.

\section{Brief History}

\subsection{Evolution of School Libraries in Hungary}

The first school library in Hungary was founded in 996, and it is open nowadays, but it was not a real school library. It was a monastery library, since the first school opened in Pannonhalma in the Benedictine Monastery. (The Hungarian state was established in 1000.) 
The school libraries in Hungary as they are today: functionally separated but integrated into the schools, trace back to the 18th century, in line with the European tradition.

Originally, school libraries were in charge of providing teachers, and later they were opened to the students as well. One of its early Hungarian document is from 1621 is from Sárospatak. Legislation is rooted back to the Ratio Educationis (Maria Theresa) of 1777, which requires secondary schools to have a library for teachers. After the introduction of compulsory schooling (1868), in 1881 school libraries were made compulsory in elementary schools too, and were regulated centrally. This regulation served as a model for other type of schools.

In the 19th century, regulations increased the number of school libraries, and significant collections were created, many of which still exist today. In 1902, the first school library manual was published to assist the work of librarians, but the library profession did not give much importance to this type of library yet.

After the Second World War, in the spirit of socialist reconstruction and in line with international trends, the need for school libraries was reinforced, a network was organized, but the collections were rooted ideologically. In 1958 the first methodological center, the National Educational Library was established which accelerated the methodological development. (eg: specialized journal, guides, supervision)

After 1970 remarkable school libraries and librarians shaped the development of school libraries. The issue of lifelong learning, the school libraries, the library pedagogy were topics of both the librarian and the educational debates. Consequently, library instruction became part of the core curriculum, was included in grammar subject. This resulted in the spreading of higher quality library pedagogical work. As a result, the profession grew stronger.

The post-1989 education act continued to require school libraries, and the new and "only" core curriculum laid greater emphasis on library instruction in cross-curricular frame within IT and grammar courses. This represents a significant change in approach.

From 1997, a paradox emerged from the tension between the increase in tasks required by the National Core Curriculum and the unfavorable staffing standards of the Public Education Act. (Less people had to complete significantly more librarian and library pedagogical tasks in the school library in less time.) 


\begin{tabular}{|c|c|c|c|c|c|c|c|c|c|}
\hline \multirow{6}{*}{ 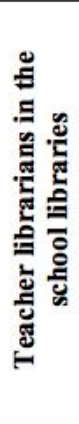 } & \multirow{2}{*}{$\begin{array}{l}\text { 21st } \\
\text { cent }\end{array}$} & \multirow{2}{*}{\multicolumn{6}{|c|}{$\begin{array}{l}\text { Outstanding } \leftrightarrow \text { dying school libraries } \\
\text { Problematic operating conditions }\end{array}$}} & 2019 & Finding vocation \\
\hline & & & & & & & & 2012 & Significant financial \\
\hline & \multirow{4}{*}{$\begin{array}{l}\text { 1970- } \\
90 \text { 's }\end{array}$} & \multirow{4}{*}{\multicolumn{5}{|c|}{$\begin{array}{l}\text { Formation of professional identity } \\
\text { The strengthening of library pedagogy }\end{array}$}} & 1997 & \multicolumn{2}{|c|}{$\begin{array}{l}\text { Cultural and education legal } \\
\text { background is weakening }\end{array}$} \\
\hline & & & & & & & 1995 & \multicolumn{2}{|c|}{$\begin{array}{l}\text { National Core Curriculum } \\
\text { (organic incorporation) }\end{array}$} \\
\hline & & & & & & & 1986 & \multicolumn{2}{|c|}{ 1st school library NGO } \\
\hline & & & & & & & 1978 & \multicolumn{2}{|c|}{$\begin{array}{l}\text { Library instruction in the } \\
\text { curriculum (mother language) }\end{array}$} \\
\hline \multirow{2}{*}{ 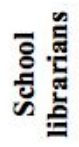 } & \multirow{2}{*}{$\begin{array}{l}1950- \\
1960 \text { 's }\end{array}$} & \multirow{2}{*}{\multicolumn{4}{|c|}{$\begin{array}{l}\text { Reorganization } \\
\text { Stronger involvement in school life }\end{array}$}} & 1959 & \multicolumn{3}{|c|}{ 1st school library journal } \\
\hline & & & & & & 1958 & \multicolumn{3}{|c|}{ National school library network } \\
\hline \multirow{3}{*}{$\begin{array}{l}\text { 롤 } \\
\text { 兽 } \\
\overline{\bar{\delta}} \\
\text { 总 }\end{array}$} & \multirow{2}{*}{$\begin{array}{l}\text { 19th- } \\
\text { 20th } \\
\text { cent }\end{array}$} & \multirow{2}{*}{\multicolumn{3}{|c|}{$\begin{array}{l}\text { Increasing the number of school } \\
\text { libraries } \\
\text { Formation of significant collections }\end{array}$}} & 1902 & \multicolumn{4}{|c|}{ 1st school library manual } \\
\hline & & & & & 1881 & \multicolumn{4}{|c|}{ Library is obligatory in elementary schools } \\
\hline & $\begin{array}{l}\text { 18th } \\
\text { cent }\end{array}$ & \multicolumn{2}{|c|}{$\begin{array}{l}\text { The roots of today's school } \\
\text { library operations }\end{array}$} & 1777 & \multicolumn{5}{|c|}{ Library for teacher is obligatory in secondary schools } \\
\hline \multirow{2}{*}{ 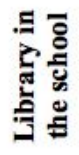 } & \multirow{2}{*}{$\begin{array}{l}10 \text { th- } \\
17 \text { th } \\
\text { cent }\end{array}$} & \multirow{2}{*}{$\begin{array}{l}\text { Libraries in the } \\
\text { secondary schools }\end{array}$} & 1621 & \multicolumn{6}{|c|}{ Students may use the library for teacher } \\
\hline & & & 996 & \multicolumn{6}{|c|}{ 1st school (it had library) } \\
\hline
\end{tabular}

Figure 1: Stages of development of Hungarian school libraries

\subsection{Evolution of Hungarian School Librarianship}

The teacher librarian profession has been evolved and developed over decades (Figure 1). In the 1960s, more and more teachers became school librarians, while others went to work to schools as librarians.

After 1970 remarkable school librarians shaped the development of school libraries. Thanks to their work the school librarianship became an independent profession and the methodology of library pedagogy was elaborated as well.

Thanks to the legal regulations and the pedagogical revival, by the 1970s there were more and more school librarians, as a result in the 1980s the professional elite had been "emerged". Through their theoretical and practical work, they had highly contributed to the development of the profession and to the start of professional self-organization.

The most important process of the last 30, or even the last 50 years, has been the evolution of teacher librarian profession, in emerging of self-awareness, self-determination and in finding vocation. Our NGO Hungarian School Library Association (HuSLA) played a significant role in it. Its organizational and naming changes reflects the stages of the development. (Figure 2)

We have already found our professional identity. We believe that there is an independent profession in the intersection of librarianship and teacherhood, with specific tools and methods tied to information literacy and libraries, but clearly in the service of education. It is no coincidence that we always quote Mihály Balogh: Librarian? Teacher? Teacher Librarian! We believe that a school with an age-appropriate library, 
offers significantly more to the student, to the teacher, and thus to the society. Many changes are needed to ensure that the intellectual, personal and physical conditions of each school are sufficient, and every student are assured, but the vocation and mission is already given.

This professional development also resulted in differentiation. Today, we legally distinguish teacher librarians and librarians (who do not have teacher qualification) in a school library. According to the spirit of the law, it is mandatory to employ a teacher librarian, whose work and the operation of the library is assisted by other school librarians. In law enforcement, maintainers and heads of institutions they increasingly act differently.

\subsection{History of the Hungarian School Librarian's Association}

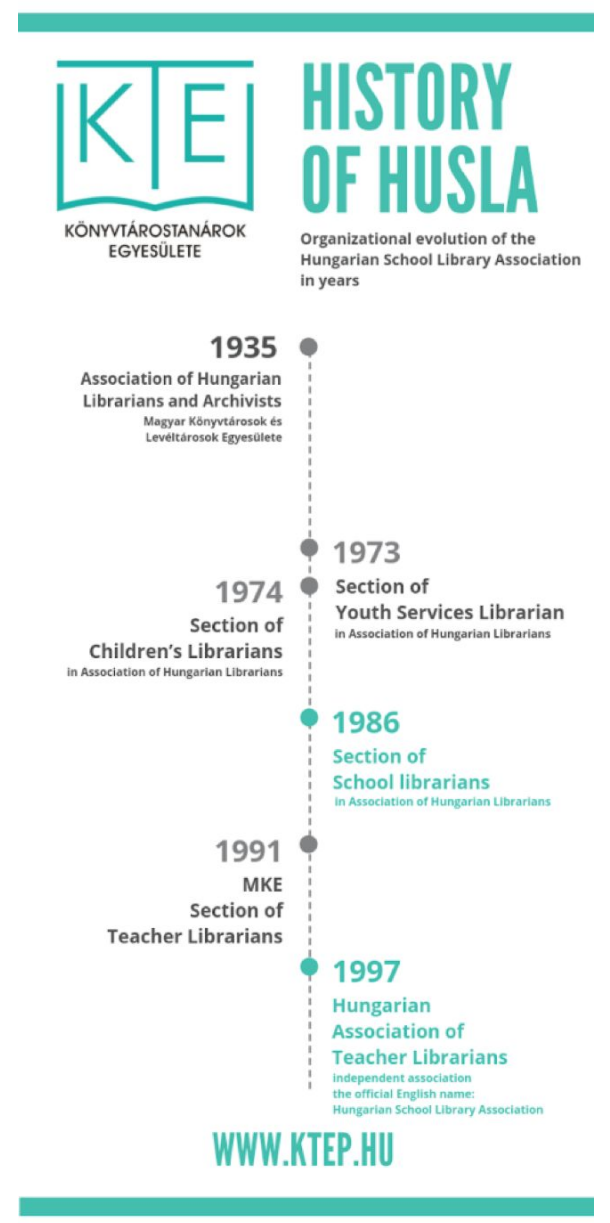

Figure 2: History of the Hungarian School Librarian's Association in years

More and more school librarians who do not have similar colleagues in their school have found a professional community in the county or specialist sections of the Association of Hungarian Librarians (AHL; Magyar Könyvtárosok Egyesülete). So many joined the Section of Youth Services Librarian, which was formed in 1973 and the Section of Children's Librarian, which began in 1974. The latter was joined by primary school librarians, while the former by secondary school librarians. 
But over time they felt that the school defined their professional tasks, problems and methods more strongly than the age group, so they initiated the establishment of an independent section at AHL. Its aim was to serve the library and education at the same time.

Independence was not easy, but in 1986 the Section of school librarians was established.

The next step in the profession's self-definition, when the section was renamed in 1991, was the AHL Section of Teacher Librarians. There were two reasons behind the name change: The change of the name of the profession was intended to express the members' double affiliation - public education and library more precisely than before, and the change in the organizational form seemed more suitable for expressing the more independent legal personality.

Full independence came in 1997. The former AHL section then continued to operate as an independent legal entity under the name Hungarian School Library Association (Könyvtárostanárok Egyesülete, literally Teacher Librarian Association; The official English name School Librarian's Association, HuSLA not a good translation). HuSLA has become an associate association of AHL, as a result of which the members are also members of AHL. Witnesses of the events say that the motive of creating a new association was fueled primarily by professional needs and financial possibilities.

2006 is another milestone in the professional development in the life of the association: Twenty teacher librarians, who define our profession, were awarded with the HuSLA's Commemorative Medal (KTE emlékérem) for the 20th anniversary of the independent association. For the first time, the members received the first volume of the Small HuSLA Books (Kis KTE könyvek) series.

In the 1990s the association started to participate in the preparation of legal acts, prepared submissions and consulted with the Ministry of Education and Culture. Starting in 2012, opportunities to cooperate with the Ministry of Human Resources narrowed, leaving unanswered submissions.

In 2016, joining the Civil Platform for Public Education (CKP) was a new direction in professional advocacy, where KTE worked together with many more and new teacher, parent and student organizations, to raise awareness on the impact of school libraries in the quality of education. (Dömsödy, Pataki \& Kámán, 2017)

Over 33 years, HuSLA has worked with a variety of organizations. All in all, it can be stated that the professional double bond appears in the list of partners, but the library focus is stronger. In addition, there is a smoother co-operation towards personal interactions (workplace, other organizational commitment).

Relations with their international organizations (IASL and IFLA School Library Section) are intensifying again, but due to linguistic, material and capacity issues, it is hard to maintain them.

\section{School Libraries Nowadays}

\subsection{The Statistic - How many of us?}

We do not have reliable data on the number of school libraries neither on the number of people working in school libraries. The October 2018 public official figures are shown on the table below (Figure 3). There is no published data on librarians and teacher librarians. According to a 2017 datas (from the request for statistical data from the Educational Authority), there were 1,360 more than half-time teacher librarians and an additional 462 school librarians without teacher qualification.

International Association of School Librarianship

https://iasl-online.org 


\begin{tabular}{|c|l|l|l|}
\hline & Sum & Has Library & Percent \\
\hline $\begin{array}{c}\text { School- sites (one school may have more } \\
\text { places) }\end{array}$ & 14.182 & 3.988 & $28,1 \%$ \\
\hline$\bullet \quad$ From this has classroom: & 6.513 & 3.379 & $51,9 \%$ \\
\hline$\bullet \quad$ From this is the center of school: & 3.004 & 2.289 & $76 \%$ \\
\hline$\bullet \quad$ From this has 8 classrooms & 3.934 & 3.004 & $76,4 \%$ \\
\hline
\end{tabular}

Figure 3: Number of school libraries in 2018

More detailed data (Dömsödy, 2017) shows that the supply of high schools and dormitories is better, as well as in schools where the library is located in the main building, or if they are placed in economically better performing regions.

\subsection{Regulations}

In Hungary, school libraries are maintained by the system of education. This includes kindergartens, primary schools, secondary schools and secondary vocational education. As a consequence, its operating conditions and the tasks to be performed are defined by the public education legislation. There is no independent school library legislation, but the Public Education Act and the decree of school operation include the most important directives on operating school libraries. In addition, the regulations that generally apply to the school and the teacher also apply to the school library and to the teacher librarian.

The most important directives are:

- a library is compulsory if the school provides general education,

- the teacher librarian must have both librarian and teacher qualification,

- compulsory work hours for teacher librarians are opening hours and library use hours,

- separate management of textbooks,

- minimum requirements: three thousand documents, free shelves, one computer, registers, space for one class, open every school day, library pedagogical program, established professional boundaries.

Library user education is also governed by public education, the curricula of public education have included such elements since 1978. The current National Core Curriculum (2012) and the curricula based on it follows a three-fold structure:

- common requirements for all subjects (cultural domains): parts of the learning methodology and digital competency,

- the subjects of mother tongue and IT incorporate the basic requirements of library use for grades 1-10 in a total of approx. 10-12 hours, 
- each subject has library-related elements (eg, maps, dictionaries, history of libraries, citation).

A new National Core Curriculum is being developed, the first version of which does not include library instruction unit in its framework. This raises a variety of professional questions, but unlike in previous years, there is now no library expert on the working committee. The problem is exacerbated by the centralization process, which allows deviation from central curricula to a lesser extent. In other words, the content of the core curriculum for school practice shapes the entire school program.

Curricula also fundamentally defines the requirements for school library services (eg, rules for collections, extracurricular activities).

Library legislation only regulates the process of collection management in school libraries. Naturally, various international and national library standards are in use as well.

In summary, we can say that the legal framework for school libraries is provided by Public Education Act, but the possibility to interpret it unfavorably is open. The technical specifications need to be updated. The curriculum background shows a worsening trend from a very good position in 1995. The last 20 years have helped to develop good practices, but these have not been integrated in the pedagogical culture of all schools yet.

Unfortunately, the new core curriculum seems to omit library program, what is a major threat to the school librarian community. Whatever effort the profession makes the government is not responding to it and not open to invest in school libraries.

\subsection{The Work in the School Library}

The obligatory standard services are very traditionally and general: collection development, circulation, reference services, information about other libraries, curricular and extracurricular activities.megt

Beside standard services, which are provided in most school libraries, teacher librarians organize competitions, commemorations on different events, exhibitions and contests. They often join quizzes offered by other libraries. Central, nation-wide reading and library promotion programs are not typical. A national contest which mobilizes school libraries is, the Péter Bod's National Contest for Information Literacy and Library Use.

In addition to traditional library activities, school libraries are involved in providing free textbook provision. It needs a lot of administration. Due to free course book supply by the states, the school libraries are flooded with course books.

Most of the teacher librarians also have other specialist qualifications. In recent years, more and more colleagues have been teaching other subjects for economic reasons. This often resulted in a loss of service time.

\subsection{Support of School Libraries}

School libraries and colleagues received and receive support from many different sources. The most typical are: 


\subsubsection{Pedagogical Libraries}

In 1956, the National Educational Library (www.opkm.hu) was established by decree, with the main tasks of organizing and supporting the school library network. Between 1959 and 1989 the institute was able to fulfill its mission, has done extensive professional work in the field. After the change of regime in 1989, the network ceased to exist, and this activity of the library was also reduced. But there are still services for school libraries, but to a much lesser extent. Eg: Book and Education a specialist journal is still alive, a school library manual has been published, there are conferences and the library organizes the Peter Bod's National Contest of Information Literacy and Library Use.

The network of pedagogical institutes was established in 1985 to support the schools and teachers in every 20 county. Their libraries helped the school libraries professionally and methodically as well. Pedagogical librarians worked closely together to coordinate the work of school library experts and educational advisors in their area. In-service training, conferences, competitions and personal assistance were organized. In 2012 new pedagogical centers were established. It was not obligatory to have library, therefore the formerly flourishing libraries have been abandoned. And only 3-4 have library too. Currently there are several centers with school library advisors, who primarily provide individual counseling.

After the network of Pedagogical Libraries was eliminated the Hungarian School Librarian's Association overtook the responsibility to support the school librarian community with methodology of library pedagogy.

\subsubsection{The Civil Association}

We have already mentioned many times how many areas Hungarian School Librarian's Association (HuSLA) does for school libraries (www.ktep.hu).

The main function of HuSLA is to provide professional support and organize discussion for Hungarian school library professionals working in public and higher education, teacher training.

The Association was founded in 1986 and since then it has been playing its part in the librarian professional life in Hungary. The Association is an open organization: every teacher librarian and school librarian and other teacher or librarian or other people can become a member.

The top priority aims and the activity of the Association:

- To help library professionals enforcing their interest.

- To provide up-to-date information for its members. (newsletter, blog, Facebook, mailing list)

- To help its members to enrich their professional knowledge. (books, conferencies)

- To gain acknowledgement for school librarian profession. (prize for teacher librarians, International School Library Month, media appearance)

- To encourage discussion and collaboration among professional organizations.

The aim of the HuSLA had always been to support the members' self-learning, and now we see our mission in helping our colleagues' professional development, and their change of mind-set. Libraries, pedagogical approaches and methods have changed a lot. The current infrastructural conditions for school

International Association of School Librarianship

https://iasl-online.org 
libraries are very poor, but this should not be a barrier to professional renewal. Therefore, we not only put current issues on the agenda, but we use methods that are more appropriate to today's pedagogical standards, which take action-oriented and interactive forms. In addition to publishing our colleague's writings in our publications, we develop their ideas further in a collaborative creative process.

The association never had an employee. Members of the Board have always been volunteers. This requires lot of energy, since over the time, the central and regional methodological institutions and services which supported school libraries have gradually have downgraded and ceased. This phenomenon increased the need for help. In recent years, there has been more opportunity, together with more work, due to the growing number of collaborating partners and the intensification of international relations. Setbacks appear due to the lack of time to fulfill important tasks.

The need for individual or professional advocacy increases (eg: termination of statuses, unlawful classification, unfavorable legislative amendment plans, working committees). Over the years, we have provided a growing number of programs, and publications to the membership and to the wider professional environment.

The values represented by HuSLA determine the decisions, topics and activities of the Board: 1 . Advocacy for school libraries for quality education 2. Equitable access to information and library services 3. Training information literacy 4. Fostering lifelong learning 5. Supporting intellectual freedom 6. Maintaining an open, inclusive, and collaborative environment.

\subsubsection{Teacher Librarian Training}

Since the introduction of Bologna training in Hungary in 2006, it has been possible to obtain a diploma of library pedagogy. Currently, four universities offer this training.

Prior to 2006, LIS students of teacher training colleges had the possibility to attend library education courses, but it was not stated in their diplomas.

\subsubsection{Special Literature and Textbook}

The last Hungarian school library handbook was published in 1993 by National Educational Library and Museum (NELM). But we have a fresh library pedagogy handbook as well (2018, HuSLA), which presents the theoretical aspects and tries to assist to put them into practice.

Book and Education (Könyv és Nevelés) is a journal published by the NELM. The journal deals with the special fields of library science, particularly school libraries, school books, reading promotion, children and youth literature. Each article is shortly summarized in English and in German. The journal appears 1966-1987, and quarterly since 1999, but it has an antecedent 1959-1966.

In 2006 the Hungarian School Librarian's Association (HuSLA) decided to foster library pedagogy by publishing a series of methodology books (Small HuSLA Books, Kis KTE könyvek) which help school librarians to pass on age appropriate and skill-specific contemporary knowledge. Disseminating the impact of this editorial work to the Hungarian school librarian's community might inspire the participants of the conference. The last volume, number 10, was published in 2018. The writings for the practical volumes are selected by HuSLA through a call for applications, and the winning applicants are assisted by the editors in developing their work for publication.

International Association of School Librarianship

https://iasl-online.org 
The translation of the IFLA School Library Guidelines, 2nd edition was published in 2016. The Hungarian translation was the fourth language, the Guideline was translated into. The Guideline was promoted by various programs and publications by HuSLA. (eg. it was sent to key person of education at the International Book Giving Day, was promoted by printed infographic and workshop). The main aim was to help teacher librarians to adapt the standards into their practice. The best practices were presented at a regional conference.

Before 1989, there were some manuals for library use for children and young people, but there was only one textbook. The change of regime in 1989 brought freedom to the textbook market.

In the 1990s, eleven types of library use manual were published, the last one in 2001. Today there are some IT and mother tongue textbooks with chapters on library use, but no concise and comprehensive textbook is available. This is an obstacle to the modernization of the curriculum.

\subsubsection{A Competition for Library Users}

Péter Bod's National Contest of Information Literacy and Library Use (Bod Péter Országos Könyvtárhasználati Verseny; Péter Bod was a famous librarian in the 18th century) organised by the National Educational Library and Museum (NELM).

It is not only a competition, but also an attempt to renew the content and methodology of the profession. The commission of the contest endeavours to provide new types of assignments, including examples of new approaches to information literacy instruction.

The most essential aim of this contest is the complex competency development and talent management of grade 7-10 (13-16 aged) pupils, more specifically the development of their skills of information literacy and library use, as well as the development of reading comprehension, the ability to think logically and creativity and thereby to develop the competences needed for independent learning. The competition was started in nationwide scale in 1993 for 5-12 grade students.

During the contest no lexical knowledge is required, rather they are required to use their various competencies to solve practical problems by individually selected resources. From the beginning on, the competition worked with project-oriented assignments too. Students are expected to know and use several traditional and electronic sources of information and other library reference tools according to the National Core Curriculum, in order to interpret and analyze information and then present their inquiry properly to the jury.

Every year the tasks of the competition are organized around a central actual theme trying to strive for diversity.

Some examples:
- 2010/2011 - Children's and youth literature in the EU
- 2011/2012 - Copernicus and the Solar System
- 2012/2013 - A diverse world - biodiversity in literature, in arts and in science
- 2013/2014 - Miklós Radnóti (a Hungarian poet) and his period
- 2015/2016 - Folk music, Béla Bartók and his period
- 2016/2017 - 200 years ago - heritage of 1817
- 2017/2018 - Water
- 2018/2019 - Power and democracy

International Association of School Librarianship

https://iasl-online.org 
Within the given subject, students can encounter a variety of topics and they not only have to seek information and data, but also have to find real solutions with the help of different information sources. The objective is to improve the students' subject knowledge and library skills and at the same time advance their interdisciplinary understanding.

The competition consists a written test practice and an oral round. The written worksheets contain age-appropriate tasks, which focus on data analyzes other contexts and the interpretation. The contest is organized in a different school library environment, therefore it is important that the contesters are able to orientate in any libraries with ease, since they have only 90 minutes to solve the tasks. To prepare for this competition, similar types of tasks from previous contests can be found in our test-bank. (http://bod.opkm.hu)

\section{The Library Pedagogy Program for school libraries}

In spite of difficulties Hungarian school librarianship has much strengths but needs to be improved in many fields yet. Luckily there are well operating libraries, committed teacher librarians and a good legislation. Library instruction is built into the core curriculum and included in the information science final exam still.

We believe that the services of school library, the knowledge of teacher librarian and the information literacy instruction foster quality education. The school library is beneficial for all stakeholders of education and everybody has the right to have access to this service. As the IFLA/UNESCO School Library Manifesto states: "The school library provides information and ideas that are fundamental to functioning successfully in today's information and knowledge-based society. The school library equips students with life-long learning skills and develops the imagination, enabling them to live as responsible citizens." The Hungarian teacher librarians share this view and do their bests to accomplish it.

So we're in a difficult situation, but we need to carry on, and find a way out. The solution is based on reinforcing a pedagogical culture that is focuses on students' autonomy and thus considers information literacy indispensable.

A possible way to save the school libraries and the teacher librarian profession is to elaborate the school Library Pedagogy Program (LPP) and declare how school libraries can support information literacy.

At first it should not be called as school library program, because it is not for the school library, but for the school, neither an information literacy program because, librarian expertise plays a central role in it, and reading promotion is important as well. Therefore, we use the term LPP. It incorporates all aspects of education and learning which are related to library, information sources, and information, and everything what is done for it or with it.

Subject based library programs and good cooperation with teachers can help students to become independent learners in their whole life. School libraries are challenged to prove the society that they are change agents in teaching critical thinking and real lifelong learning skills in the digital era.

In Hungary LPP is mandatory from 2012, and the decree states that the school library is an institutional unit, which coordinates the school's library-pedagogical activities. This is important because it expresses that library pedagogy is an issue of the school, not only the teacher librarian's matter.

The school library serves the school, it means that LPP is a more sophisticated, more detailed adaptation of the school's pedagogical program to the library. It contains information literacy enforcement and

International Association of School Librarianship

https://iasl-online.org 
reading promotion in a unified structure. This helps to see the complexity of the procedure systematically, this way it helps in its planning, coordination and implementation.

Subsequently we recommend that colleagues include the followings in the LPP:

-general goals, mission statement

a more detailed target system

-situation analysis

'network (participants in implementation)

-library use curriculum

$\cdot$ IL objectives and the content of other subjects

-measurement, evaluation

·extracurricular activities, specialties

'non-occupational activities (common media, bulletin board ...)

talent support

It is important to show all of these in a well-constructed structure by grade and subject. We recommend the use of tables and flowcharts.

The fact that the LPP is a school-level document also means that it is prepared by the librarian teacher in cooperation with the teaching staff. Teacher librarians not only coordinate the implementation, but also the preparation. The preparation process is already an important part of developing a pedagogical culture at school. That is why we think that the project in 2015 was a good initiative, which suggested that the librarian teacher and the head of the institution work together on LPP with the teaching staff.

In Hungary, only a few such comprehensive LPPs are currently available. Many LPPs only have a library use curriculum. But there are good practices.

We think that LPPs could be upgraded to a municipal version. Various professionals could be involved. Those who work with education, culture and children and young people, even with adults must be engaged: school librarians, children librarians, other librarians, teachers, kindergarten teachers, health visitors, police officers, social workers, museum educators, sports trainers... So far, this is a theoretical proposition, but there may be an answer to the challenges. Such collaboration can have two results: to develop more effective IL for children and adolescents, and increase their attachment to libraries and reading. On the other hand, inter-professional relationships could bring the rise of the prestige of school libraries.

\section{REFERENCES}

Dömsödy, A. (2017.11.07): Iskolai könyvtárak Magyarországon - Amit a jog és a statisztika mutat. [School Libraries in Hungary - What law and statistics show.] In: Fülöp Hajnalka (föszerk.): Modern Iskola, Budapest, Könyvtárellátó Nonprofit Kft., Retrieved from:

International Association of School Librarianship

https://iasl-online.org 
http://moderniskola.hu/2017/11/iskolai-konyvtarak-magyarorszagon-amit-jog-es-statisztika-mutat /

Dömsödy, A., Pataki, M., \& Kámán, V. (2017) Acting together for the civil society and the quality education Acting under checked umbrellas. Paper presented at: IFLA WLIC 2017 - Wrocław, Poland - Libraries. Solidarity. Society. in Session 140 - Management of Library Associations. Retrieved from: http://library.ifla.org/1761/1/140-domsody-en.pdf

IFLA/UNESCO (1999) School Library Manifesto. Retrieved from: https://www.ifla.org/publications/iflaunesco-school-library-manifesto-1999

Minister of Human Capacities (2012) 20/2012. (VIII. 31.) EMMI rendelet a nevelési-oktatási intézmények müködéséről és a köznevelési intézmények névhasználatáról. [Decree of Minister of Human Capacities on the Operation of Public Educational Institutions and the Use of the Name of Public Educational Institutions.] Retrieved from: http://njt.hu/cgi_bin/njt_doc.cgi?docid=154155

\section{Biographies}

\section{Dömsödy, Andrea}

School library expert of NELM and teacher of library pedagogy at the Eszterházy Károly University. Vicepresident of HuSLA. Author of numerous publication in topic of school library.

Pataki, Marianna Edit

Teacher Librarian and Art Teacher at a Spanish-Hungarian bilingual high school. Board member of the HuSLA. Experienced in creating school library program, planning curriculum and embracing creativity in the school library. 